\title{
MANAJEMEN PENGEMBANGAN KECAKAPAN HIDUP UNTUK MENINGKATKAN KEMANDIRIAN SANTRI DI PESANTREN
}

\section{MANAGEMENT OF LIFE SKILLS DEVELOPMENT TO IMPROVE STUDENT INDEPENDENCE IN ISLAMIC BOARDING SCHOOL (PESANTREN)}

\author{
Siti Rohmah'a \\ ${ }^{1}$ Program Studi Manajemen Pendidikan Islam, Fakultas Keguruan dan Ilmu Pendidikan, \\ Universitas Djuanda Bogor, Jl. Tol Ciawi No. 1 Kotak Pos 35 Ciawi Bogor 16720 \\ a Korespondensi: Siti Rohmah, Email: siti.rohmahghanem@gmail.com \\ (Diterima: 21-08-2017; Ditelaah: 22-08-2017; Disetujui: 25-10-2017)
}

\begin{abstract}
This study aims to determine how the management of development and life skills education in improving the independence of students and inhibiting factors and support the development of life skills to increase independence in Islamic Boarding Schoola Hasmi of Bogor. This research method using descriptive qualitative approach method. Data were collected through participant observation technique, documentation interview and triangulation based on field phenomenon. The result of the management of life skills development in Islamic pesantren Hasmi uses two approaches: 1). Implementation of an integrative curriculum system, referring to the Ministry of Religious Affairs, and the Ministry of National Affairs; 2). Special programs for pesantren are: a) personal skill: general lecture, book review, b) social skill: training of da'iyah, muhadatsah, and consecration, c) academic skill: bahsmul masail, d) vocational skill: catering project, Clothing Hisami venture, market day. Supporting factors are a vision, philosophy, expert teacher, facilities and infrastructure, interest, motivation and working relationship. Some of the inhibiting factors are differences in mindset, the ability of students, and the lack of time allocation.
\end{abstract}

Keywords: development management, life skills education, pesantren, self-reliance students.

\begin{abstract}
ABSTRAK
Penelitian ini bertujuan untuk mengetahui bagaimana manajemen pengembangan serta pendidikan kecakapan hidup dalam meningkatkan kemandirian santri serta faktor penghambat dan pendukung pengembangan kecakapan hidup untuk meningkatkan kemandirian di Pesantren Islam Hasmi Bogor.Metode penelitian ini menggunakan metode pendekatan kualitatif deskriptif.Data dikumpulkan melalui teknik observasi partisipan, wawancara dokumentasi dan triangulasi berdasarkan fenomena dilapangan. Hasil penelitian manajemen pengembangan kecakapan hidup di pesantren Islam Hasmi menggunakan dua pendekatan:1). Penerapan sistem kurikulum integrative, mengacu pada Kementerian Agama, dan Kementerian Nasional;2). Program khusus pesantren, yaitu: a) personal skill: kuliah umum, kajian kitab, b) sosial skill: pelatihan da'iyah, muhadatsah dan kerja bakti, c) akademik skill: bahsmul masail, d) vokasional skill: proyek tata boga, tata busana Hisami usaha, market day. Faktor pendukung yaitu visi,falsafah, guru ahli, sarana dan prasarana,minat, motivasi dan hubungan kerja.Beberapa faktor penghambat yaitu perbedaan pola pikir, kemampuan santri, serta minimnya alokasi waktu.

Kata kunci: kemandirian santri, manajemen pengembangan, pendidikan kecakapan hidup, pesantren.
\end{abstract}


Rohmah S. 2017. Manajemen pengembangan kecakapan hidup untuk meningkatkan kemandirian santri di pesantren. Tadbir Muwahhid 1(2): 177-182.

\section{PENDAHULUAN}

Kesejahteraan dan kekuatan suatu bangsa tidak hanya pada melimpahnya kekayaan dan seberapa hebat alat-alat yang dimiliki. Akan tetapi sangat ditentukan oleh kualitas sumber daya manusia. Dengan sumber daya manusia yang berkualitas bangsa ini akan mampu mengelola dan memanfaatkan kekayaan dengan sebaik-baiknya, serta dapat menjalankan dan menciptakan alatalat tersebut. Untuk mewujudkan terciptanya sumber daya manusia berkualitas salah satu proses yang dilakukan adalah melalui pendidikan.

Pendidikan adalah proses pematangan kualitas hidup, melalui proses tersebut manusia dapat memahami apa arti hidup dan hakikat hidup serta untuk menjalankan kehidupan secara benar(Ramayulis, 2012).

Oleh karenanya pendidikan diyakini sebagai wadah yang dapat mengantarkan manusia menjadi pemimpin (Al jamali, 1995). Sejalan dalam firman Allah dalam Alqur'an surat al-Baqarah: 30. Artinya: “Dan ingatlah ketika Tuhanmu berfirman kepada para Malaikat: "Sesungguhnya aku hendak menjadikan seorang khalifah di muka bumi."

Sistem pendidikan di Indonesia saat ini masih mengedepankan segi kognitif, padahal pendidikan yang mampu mengembangakan potensi peserta didik yaitu dengan pengembangan kecakapan hidup (life skill) untuk bekal praktis pada masa mendatang dalam memecahkan masalah di kehidupannya.Salah satu model pendidikan yang memberikan kemajuan dunia adalah pondokpesantren.pesantren adalah lembaga pendidikan yang mempunyai kekhasan tersendiri, yang berbeda dengan lembaga pendidikan lainnya. Pesantren ideal adalah pesantren yang mengajarkan ilmu Agama serta ilmu umum( AzraAyzyumardi, 1999).

Pesantren Islam Hasmi Putri adalah salah satu pesantren khusus yang mempunyai program manajemen pengembangan kecakapan hidup. Melalui program unggulan tata busana, tata boga, house keeping, bina da'iyah kepanduan dan tahfdz. Namun peneliti memfokuskan pada skill di bidang tata boga dan tata busana.Pesantren Islam Hasmi cukup teratur dan terarah sesuai dengan sistem yang diterapkan. Sehingga begitu penting mengetahui apa penyebab terkelolanya dengan baik manajemen pengembangan kecakapan hidup untuk meningkatkan kemandirian santri di Pesantren Islam Hasmi. Oleh karena itu peneliti ingin meneliti dari satu sisi manajemen pengembangan kecakapan hidup (life skill) di bidang tata boga dan tata busana untuk meningkatkan kemandirian santri.

Penelitian ini dapat dikaji lebih dalam jika ditentukan fokus dan sub fokusnya. Batasan masalah masalah difokuskan mengenai manajemen pengembangan kecakapan hidup tata busana dan tata boga untuk meningkatkan kemandirian santri di Pesantren Islam Hasmi Bogor.Berdasarkan latar belakang dan batasan masalah diatas, maka permasalahan penelitian dapat dirumuskan "Bagaimana Manajemen Pengembangan Kecakapan Hidup Untuk Meningkatkan Kemandirian Santriwati di Pesantren Islam Hasmi Bogor?"

Berdasarkan uraian rumusan masalah yang ada dalam penelitian, maka tujuan yang hendak dicapai dalam penelitian ini adalah untuk mengetahui pelaksanaan pengembangan kecakapan hidup (life skill) di Pesantren Islam Hasmi Bogor.Kemudian 
untuk mengetahui faktor pendukung dan penghambat pelaksanaan manajemen pengembangan kecakapan hidup (life skill) di Pesantren Islam Hasmi Bogor.

\section{MATERI DAN METODE}

\section{Materi}

\section{Manajemen Pengembangan Kecakapan Hidup}

Kamus Besar Bahasa Indonesia menjelaskan bahwa penggunaan sumber daya yang efektif untuk mencapai sasaran pimpinan yang bertanggung jawab atas jalannya perusahaan dan organisasi. Menurut Hikmat, adalah ilmu dan seni mengatur proses pemanfaatan sumber daya manusia secara efektif, menggerakan seluruh organisasi sehingga mampumewujudkan harapan dan cita-cita organisasi.

Manajemen secara etimologi berasal dari Bahasa Inggris yaitu dari kata kerja to manage yang artinya mengatur mengurus menggerakan dan mengelola (Amtu Onisimus, 2011). Sedangkan pengertian manajemen secara terminologi menurut terry dan piaget adalah suatu lemabaga organisasi yang memiliki perencanaan, penorganisasian, pelaksanaan dan pengawasan untuk mencapai tujuan yang telah ditetapkan bersama secara stakeholder.

Sementara pengembangan menurut safri adalah proses memperkenalkan atau mengkomunikasikan segala "sesuatu " yang asing pada kelompok masyarakat dan lingkungan pesantren, baik berupa ide atau gagasan.Pengembangan kecakapan hidup ialah upaya memberikan pengasahan atau pelatihan kepada peserta didik untuk dapat menjalankan tujuannya dengan baik sebagai individu, makhluk sosial maupun sebagai makhluk Tuhan (Syah Darywan 2007).

Pengembangan kecakapan hidup (life skill) dapat diartikan juga proses pengasahan yang dapat memberikan bekal keterampilan praktis, terpakai, terkait dengan kebutuhan pasar kerja, peluang usaha, dan potensi ekonomi industri yang ada dimasyarakat (Anwar 2013).

Dengan demikian pengembangan kecakapan hidup dalam konteks globalisasi sarat dengan kompetensi dimana pemenangnya sangat ditentukan oleh kualitas sumber daya manusianya. Maka dari itu pengembangan pendidikan kecakapan hidup di pesantren sangat perlu diupayakan, yang memiliki relevansi dengan kehidupan serta kebutuhan sehari-hari. Tujuan kecakapan hidup ialah untuk memfungsikan pendidikan sesuai fitrahnya, mengembangan potensi manusiawi peserta didik yang sesuai dengan karakteristik, emosional dan spiritual dalam prospek mengembangkan diri, memposisikan perannya dimasa sekarang dan yang akan datang. Sedangkan manfaat pengembangan kecakapan hidup ialah sebagai bekal bagi peserta didik dalam menghadapi dan memecahkan problem kehidupan baik sebagai warga mandiri, maupun warga masyarakat dalam bernegara (Slamet, 2014).

Adapun urgensi pengembangan kecakapan hidup ialah untuk sukses dalam kehidupannya peserta didik harus dibekali dengan keterampilan-keterampilan hidup, jujur, disiplin, amanah, sehat, bekerja keras dapat bekerjasama serta dapat mengambil keutusan (Asmani, 2013).

\section{Metode}

Penelitian ini merupakan penelitian deskrptif kualitatifyaitu suatu penelitian yang menghasilkan data deskriptif berupa kata-kata atau lisan dari orang-orang dan 
prilaku yang dapat diamati (JMoleong 2015). Metode penelitian yang mampu menggambarkan serta melakukan intreprestasi pada objek sesuai dengan apa adanya atau dapat dikatakan secara objektif (Sukmadinata 2013). Data dikumpulkan melalui teknik observasi partisipan, wawancara dokumentasi dan triangulasi berdasarkan fenomena dilapangan (Sugiyono, 2012).

\section{HASIL DAN PEMBAHASAN}

Hasil pengamatan peneliti bila mengacu pada penelitian life skill yaitu pemberian pengalaman belajar dan bekal bagi peserta didik baik yang bersifat keahlian umum (general skill) maupun keahlian khusus (sfesifik skill). Pelaksanaan pengembangan kecakapan hidup (life skill) di pesantren Islam Hasmi Bogor.

Dalam pelaksanaanya manajemen pengembangan kecakapan hidup di pesantren Islam Hasmi tidak terlepas dari fungsi-fungsi manajemen yaitu perencanaan, pengorganisasian, pelaksanaan dan evaluasi.

a. Perencanaan Pelaksaaan pengembangan kecakapan hidup (life skill)

Dalam tahap perencanaan ini pimpinan menyusun gran desain sebagai bingkai pondok pesantrenyakni dalam upaya mewujudkan visi misi, melakukan kemudahan rapat kerja antara pimpinan dengan pengurus pesantren, untuk membahas beberapa program dan pembahasan terkait dengan desain pengembanganpendidikan kecakapan hidup, agar bertujuan kegiatan-kegiatan pembelajaran dapat terprogram dengan baik. Perencanaan pengembangan kecakapan hidup di pesantren Islam hasmi memiliki langkah-langkah: tujuan penegmbangan kecakapan hidup yaitu: (mewujudkan visi misi pesantren: mewujudkan generasi robbani yang mandiri dan berprestasi di bidang keimanan, ketaqwaan serta ilmu pengetahuan (imtaq dan iptek serta life skill yang unggul) ,mengidentifikasian kebutuhan, menyesuaikan kurikulum dan program kecakapan hidup.

b. Pengorganiasian melalui langkahlangkah, yaitu: membuat struktur yang fokus pada kecakapan hidup, guru yang kompeten atau memiliki keahlian. yaitu guru tata busana dan tata boga.

c. Pelaksanaan pengembangan kecakapan hidup melalui program:

1) Kuliah umum: setelah shalat subuh berjamaah diadakannya kuliah umum atau ceramah berisikan nilai-nilai kehidupan yang disampaikan oleh ustadz sarbini dan wajib dihadiri oleh seluruh santriwati. 2) Kajian kitab: pengembangan aspek personal skillsantri ialah dengan diadakannyakajian kitab. Adapun kitab-kitab yang dikaji yaitu tafsir hamka azhar, tafsir jalalin, mukhtarol hadits, yang di isi langsung oleh pimpinan pesantren yaitu Solahudin dan Andri Muzaki, serta sosial skill yaitu pelatihan Da'iyah masing-masing santri diberikan jadwal sehingga mengalami langsung baik itu materi agama ataupun tentang tata boga dan tata busana. Muhadatsah(percakapan Bahasa Arab dan Inggris) yang pelaksanaannya setiap hari minggu. 3) Jum'at Bersih (kerja bakti). Dilakukan oleh santri hari jum'at pukul 06.00-07.00 yaitu dengan membersihkan area pesantren dan santunan anak yatim dengan tujuan mempererat tali silaturahmiserta diadakan juga kegiatan peduli sosial.Penerapan pengembangan kecakapan hidup (life skill) Akademik skill.: yaitu kegiatan Bahsmul Masail (hanya terfokus pada pembahsan atau diskusi tentang kajian Islam berdasarkan referensi dari Alquran, hadits, kitab-kitab terdahulu serta pembahasan 
terkait program khusus yaitu tata boga dan tata busana. Penerapan Pengembangan Kecakapan Hidup (Vocasional Skill).

Mengingat kompleksnya tuntutan dunia usaha maupun kerja, maka dari itu pesantren Islam Hasmi di konsep dengan upaya mengintegrasikan kegiatan santri antara mengaji, menghafal, tata boga dan tata busana. Para santriwati diberikan kecakapan hidup (life skill) menjahit dan memasak karena keduanya harus memiliki seni keterampilan tersebut. Bimbingan tersebut melalui keterampilan nyata intensif, efektif dan efisien.

Adapun bimbingan melalui proyek tata busana yaitu: santri diberikan bahan kain yang dijadikan suatu bentuk baju atau laiinya dengan dilatih dari pola rancangan pakaian di laboratorium hingga mahir. Pelaksanaan proyek tata busana dilakukan pukul 07.0009.00 dibuat kelompok.Virus usaha serta Proyek tata Boga yaitu market day yang dilakukan sebulan sekali. Dan karya santri dari berbagai masakan unik di jajakan dalam bazar tersebut. Peminat pesantren dan lingkungan pesantren hingga masyarakat. Program Hisami Usaha yaitu berbagai produk makanan di masukan ke koperasi pesantren dan warung-warung warga. Dengan demikian, aspek penilaian diantaranya: kedisiplinan, kepribadian, ketekunan, ketekunan bekerja, kegiatan ibadah, kegiatan bermuamalah/masyarakat, keseriusan mendalami usaha, insiatif, bekerja kelompok atau individu. Format penilaian tersebut di isi secara rahasia oleh guru pengampu kecakapan hidup.
d. Evaluasi pelaksanaan pengembangan kecakapan hidup (life skill)
Evaluasi pelaksanaan pengembangan kecakapan hidup (life skill) dalam penilaian pengembangan kecakapan hidup santri, serta efektif program life skill pesantren Islam Hasmi, dalam evaluasinya

mengadakan Rakor (rapat kerja koordinasi) yang dilakukan setiap satu tahun sekali, untuk mengetahui pencapaian kurikulum, tingkat kemampuan santri, serta mendorong guru untuk memperbaiki metode mengajar yang telah dilaksanakan sehingga hasil evaluasi ada solusi atau perbaikan untuk pengembangan kecakapn hidup santri.

Faktor pendukung dan penghambat diantaranya adalahvisi misi,falsafah, guru ahli, sarana dan prasarana,minat, motivasi serta hubungan kerja. Sedangkan faktor penghambatnya di antaranya adalah perbedaan pola pikir, kemampuan santri, serta minim alokasi waktu.

\section{KESIMPULAN DAN IMPLIKASI}

\section{Kesimpulan}

Berdasarkan hasil penelitian dan pembahasan yang dilakukan dipesantren Islam Hasmi Bogor, bahwa faktor pendukung dalam pelaksanaan pengembangan pendidikan kecakapan hidup (life skill) di pesantren Islam Hasmi, diantaranya, visi misi, kehidupan pesantren, tersedianya guru yang kompeten dalam bidangnya, sarana prasarana yang memadai, serta hubungan kerjasama yang baik dengan pihak pengusaha. Sedangkan faktor penghambatnya yaitu perbedaan pola pikir santri, minimnya alokasi waktu atau jam belajar berkurang yang disebabkan oleh adanya sistemyang ada saat ini.

Pelaksaaan pengembangan kecakapan hidup (life skill) di pesantren sangat berperan penting dalam pengembangan sikap dan membentuk kemandirian santri.Sehingga santri ketika terjun kemasyarakat tidak hanya pandai dalam urusan agama tetapi mampu berwiraswasta dengan memiliki jiwa semangat kecakapan hidupyang ada pada diri santri.Maka dengan 
ini akan terbentuk kemandirian dalam diri santri sertatercapainya keselarasan kebutuhan antara aspek dunia dan akhirat.

\section{Implikasi}

Pelaksanaan pengembangan kecakapan hidup (life skill) begitu penting dalam lembaga pendidikan, terutama dapat direalisasikan di lembaga pendidikan pondok pesantren. Dengan tujuan adanya keseimbangan antara ilmu Agama dan ilmu umum, yang akan berdampak dalam pembentukan kemandirian pada pribadi santri serta keselarasan dalam memenuhi kebutuhan aspek dunia dan akhirat.

\section{DAFTAR PUSTAKA}

Azra, Azyumardi 2002, Modernisasi Pendidikan Islam, Jakarta: PT Logos Wacana Ilmu.
Anwar. 2012, Pendidikan Kecakapan Hidup, Life Skill Education, Bandung. Alfabeta.

Amtu, Onisimus. 2011. Manajemen Pendidikan di Era Otonomi Daerah, Konsep, Strategi dan Implementasi.Bandung: Alfabeta.

Al Jamali, Muhammad Fadhil. 1995, Filsafat Pendidikan Dalam Al-Qur'an. Jakarta: Pustaka Al-Kautsar.

Asmani , Ma'ruf Jamal. 2013. Kiat Melahirkan Madrasah Unggulan. Yogyakara: Diva Press.

Moleong, J Lexy. 2013. Metodologi Penelitian Kualitatif. Bandung: PT Rosdakarya

Sukmadinata, Syaodih, Nanang. 2013. Metode Penelitian Pendidikan Memberikan Deskriptif, Eksplasi, Prediksi Inovasi dan Juga Dasar-dasar Teori Bagi Pengembang Pendidikan.

Sugiyono. 2012. Metode penelitian kuantitatif kualitatif dan R\&D. Alfabeta, Bandung. 